Accepted refereed manuscript of:

Calderwood E \& Freathy P (2014) Consumer mobility in the Scottish isles: The impact of internet adoption upon retail travel patterns, Transportation Research Part A: Policy and Practice, 59, pp. 192-203

DOI: $10.1016 / j$. tra.2013.11.012

(C) 2015, Elsevier. Licensed under the Creative Commons AttributionNonCommercial-NoDerivatives 4.0 International http://creativecommons.org/licenses/by-nc-nd/4.0/ 


\title{
Consumer mobility in the Scottish isles: the impact of internet adoption upon retail travel patterns
}

\author{
by \\ Eric Calderwood \\ and \\ Paul Freathy*
}

Institute for Retail Studies

Stirling Management School

University of Stirling

Stirling

Scotland

FK9 4LA

j.p.freathy@stir.ac.uk

eric.calderwood@stir.ac.uk

*Contact author 


\title{
Consumer mobility in the Scottish isles: the impact of internet adoption upon retail travel patterns
}

\begin{abstract}
While there have been numerous studies of on-line shopping behaviour, the impact of internet adoption upon island communities remains largely unexplored. This is despite the identified difficulties that are encountered when attempting to access goods and services in these peripheral economies. Limitations in the transport infrastructure, inconsistent supply and restricted availability have all been acknowledged as issues affecting local retail provision. Island residents have also traditionally been required to travel to the main town or mainland in order to shop for key items. This research study examines the extent to which on-line provision has reconfigured the mobility patterns of residents in the Scottish isles and whether e-commerce has reduced the propensity of individuals to undertake shopping related travel. The findings suggest that e-commerce has had only a modest impact upon consumer travel patterns and that other situational factors moderate the identified benefits that accrue from purchasing on-line.
\end{abstract}

\section{Keywords}

Island Retailing

Internet

Consumer Behaviour

Rural Communities

Shopping Patterns

On-line shopping 


\section{Consumer mobility in the Scottish isles: the impact of internet adoption upon retail travel patterns}

\section{Introduction}

A significant body of research has sought to identify how access to the internet and on-line availability has reconfigured consumer shopping patterns. These studies have examined a range of issues relating to consumer behaviour including the factors that influence internet adoption (Hand et al., 2009), the primary advantages that accrue from on-line availability (Verhoef and Langerak 2001) and the various factors that mediate the use of e-commerce as a shopping channel (Rotem-Mindali and Salomon, 2009; Dholakia et al 2010).

Research has also examined the extent to which e-shopping has influenced consumer mobility patterns and whether on-line availability has had any impact upon the number of shopping trips made, the activities undertaken and the factors that influence an individual's decision to travel (Collins and Wellman, 2010). For example, Ren and Kwan (2009) considered the geographical distribution of shopping opportunities and whether living in areas of low retail accessibility influenced the propensity to e-shop. While a relationship was noted between retail location and the level of internet usage, the strength and extent of this association was limited. However, despite numerous studies, Hjorthol and Gripsrud (2009) maintain that the impact of e-shopping upon mobility patterns remains unclear.

Hand et al. (2009) argue that the relationship between e-shopping activity and patterns of mobility cannot be understood without reference to the geographical context within which the 
activities take place. For example, on an island, supply is often limited and products are frequently more expensive than on the mainland. As retail stores are primarily concentrated in the urban area, many individuals are also required to travel considerable distances in order to shop. Specific situational factors can therefore have an important moderating effect that serves to limit, encourage or even negate the benefits of e-commerce. The aim of this paper is twofold. First it examines whether internet availability has had an impact upon the number of shopping trips made by island residents. Secondly, it seeks to better understand these mobility patterns and explore the factors that influence an individual's decision to shop online.

To achieve the above aims, the paper is divided as follows; first, a theoretical framework conceptualises the impact and influence of e-commerce as a retail channel. This is followed by a brief discussion on the practical issues of living in an island community. After the methodology is outlined, the empirical research details the specific patterns of shopping behaviour before a series of conclusions are drawn.

\section{E-commerce and consumer behaviour}

The potential of e-commerce to reconfigure the geography of consumption has been widely discussed in the academic literature. For example, Cairncross (1997) argued that technical advances would reduce barriers to communication and lead to the death of distance. Similarly Hand et al. (2009) argued that on-line shopping represents a form of discontinuous innovation that has led to significant changes in consumer behaviour. Individuals forfeit the sensory and tactile experiences associated with physical shopping while the opportunities for social interaction are greatly reduced. However the benefits derived from e-commerce are also well 
documented (Sim and Koi, 2002; Verhoef and Langerak 2001; Wen 2009). Individuals are better informed, able to shop at a time convenient to themselves, have access to products unavailable in the local market as well as being able to save both time and money (Collins and Wellman 2010). Using the internet overcomes the pressures associated with bricks and mortar retailing (such as overcrowding, parking and queues) and allows less mobile individuals to access a wider range of goods and services (Larson 2009; Lee et al 2009). Many factors determine whether an individual chooses to shop on-line including the type, cost and complexity of the products required, the design of the site, as well as the trust placed in the retailer (Farag et al., 2006b; Hjorthol and Gripsrud 2009; Rotem-Mindali, 2007; Stranahan and Kosiel 2007; Wen 2009). Technical factors such as the availability of broadband may also impact upon the choice of shopping channel with dial up connectivity and a low bandwidth service being seen to inhibit the adoption of e-commerce (Galloway, 2007; Ren and Kwan, 2009).

The potential of technological advances to reconfigure consumer behaviour is not however new. Wigan and Morris (1981) identified how the overwhelming majority of travel trips were multi-purpose in nature and driven by personal time constraints and activity demands. In turn Salomon (1986), Mokhtarian (1990), and Lyons and Urry (2005) examined whether developments in telecommunications would impact upon individual travel patterns. While the benefits that stemmed from innovations such as teleshopping were acknowledged (Salomon and Koppelman 1988), it was also recognised that consumer mobility patterns remained complex. For example, Hjorthol (2002) identified that on-line availability did not reduce the number of trips made and acts as an additional channel that complemented conventional shopping behaviour (Farag et al., 2006a; 2007; Lee et al., 2009; Ren and Kwan, 2009; Sim and Koi, 2002; Weltevreden 2006). In contrast, the SAC (2012) noted how the 
internet could reduce the number of journeys made by consumers in rural areas. Despite the opportunity to provide time savings and reduce the number of shopping trips, the impact of ecommerce upon mobility patterns remains inconclusive (Cairns, 2005; Rotem-Mindali and Salomon, 2007).

Mokhtarian and Salomon (2002) identified a number of ways in which consumer travel patterns may be affected by the availability of on-line shopping. These included:

- Substitution - whereby trips are eliminated completely;

- Modification - where the primary purpose of the trip is altered;

- Generation - refers to trips that would not have previously taken place prior to eshopping;

- Neutrality - where e-shopping has no effect upon travel behaviour.

Specific situational factors may mediate the impact of each of these effects. For example, while on-line availability has the potential to provide an overall substitution effect, individuals may continue to travel to a particular store for retail reasons (e.g. its service, range, quality etc) or for social reasons (e.g. as a compensatory mechanism for the lack of a social network) (Hjorthol, 2009).

Couclelis (2000) sought to understand the relationship between technology and travel by examining how traditional patterns of work and leisure had been reconfigured by the internet. It was maintained that web based services have contributed to a both a blurring and 'fragmentation' of daily routines as individuals reallocate regular activities to different periods of the day or week (see also Kellerman 2010). This view is re-iterated by Hjorthol and Gripsrud (2009) who noted that technology has removed the time limitations once associated 
with many domestic activities (such as shopping). As consumers are provided with greater choice and flexibility the complexity of such patterns have been acknowledged (Habib et al 2009) and research has sought to develop typologies based upon different patterns of consumption (Barnes et al 2007; Donthu and Garcia, 1999; Ganesh et al 2010; Hjorthol 2009; Kau et al 2003; Rohm, and Swaminathan, 2004).

Uncertainty also remains over the extent to which mobility patterns and internet usage are influenced by the existing retail landscape. For example, Ren and Kwan (2009) concluded that the propensity of consumers to use e-commerce was not strongly linked to their proximity to physical stores and that patterns of usage display distinct demographic and socio-economic patterns (see also Krizek et al., 2005). In contrast, a number of other studies have maintained that individuals in urban areas have different patterns of internet usage and display different purchasing habits from those in more remote areas (Boase 2010; Boschma and Weltevreden 2008; Farag et al, 2006b; Collins and Wellman, 2010). For example, Weltevreden et al., (2008) noted that despite consumers in the more peripheral regions of Holland having the most to benefit from internet shopping, urban consumers were more likely to buy on-line.

While research has demonstrated the advantages that can accrue through internet retailing, it would appear that consumer shopping patterns remain complex. Benefits such as convenience and choice, can be moderated by a number of spatial and social dimensions. Prior to examining the extent to which e-commerce has influenced the travel - activity patterns of island residents, the paper will contextualise the research by detailing some of the unique aspects of being part of an offshore community. 


\section{Living in an island community}

The Scottish islands are amongst the most disadvantaged and economically fragile regions in the UK (Scottish Government, 2008; 2010; Copus and Crabtree,1992). This fragility has been argued to be the outcome of a number of factors including relative rurality (McEachern and Warnaby 2006), a poor support and transport infrastructure as well as low levels of economic activity (Richards 2004; Roberts 2005; Scottish Government, 2008). Employment is often low paid, part time and seasonal with few managerial positions. The majority of employment is concentrated in the main towns with individuals most likely to work in small and medium sized enterprises (Kilkenny, 2010; Scottish Government, 2008).

Many islands have also experienced a decline in their residential population over a number of years as individuals have migrated to the mainland or overseas (Mewett 1983; Morrison and Clark 2011; Prattis 1982). Moreover, those who remain are often of an older working age or have already retired. For example, by 2035 the population of the Outer Hebrides is projected to decline by over $11 \%$, while those of working age are predicted to fall by $19.5 \%$ (SAC 2012). Islands that have a permanent resident population vary quite markedly in terms of their size and access to services. Larger islands with market towns such as Kirkwall (Orkney), Lerwick (Shetland) and Stornoway (Lewis and Harris) have an established retail sector often with intense competition between local and national retailers. On other, more remote islands, communities may be serviced by a single, multi-functional retail outlet, community shop or social enterprise.

Although island residents have access to a range of goods and services, a number of retail related concerns have been identified (Shetland Islands, 2004). One common issue is the 
dependence upon imported consumer goods and services and while some products may be locally sourced, there is often a reliance upon products transported from the mainland, from abroad or via a neighbouring island community. Armstrong et al (1991) highlighted the additional transportation costs involved in supplying island retailers and noted how port handling costs, insurance and demurrage ${ }^{1}$ could add over $4 \%$ to total supply costs. While some national multiple retailers had absorbed these additional expenditures into their overall transport budgets, many local operators were compelled to pass the extra costs on to the consumer. As a consequence retail prices are often significantly higher than on the mainland. For example, Freathy and Calderwood (2013) noted how white goods were up to $25 \%$ more expensive than on the mainland.

Prior to the growth of e-commerce, the retail offer provided through physical stores was supplemented through other channels such as catalogues, mobile shops and product fairs. As will be illustrated, the majority of retail businesses continue to remain concentrated in the main island towns and residents who wish to physically visit stores are required to travel to the urban centre. For those in more rural communities the island's transport infrastructure often represents an obstacle to this activity. Not only are public transport services limited, the Scottish Government (2008) itself acknowledges that deficiencies in the road and rail network has constrained economic development on the islands.

Those retail businesses who operate in more remote locations are often small, independent operators who stock a broad but shallow product range (Byrom et al., 2003). As Skerrat

\footnotetext{
${ }^{1}$ Demurrage refers to the period a vessel is in the possession of a charter company after the time normally given to charge and discharge the cargo (lay time). Demurrage is the amount a charterer will have to pay to the ship owner for its extra use of the vessel.
} 
(1999) identified, the limited availability of good quality fresh products has the potential to negatively impact upon the diets of island inhabitants. Even for those retailers operating in urban locations, factors such as the weather, sailing times and distance to market influence the range and the availability of the offer (Byrom et al., 2001).

For many island residents conventional shopping channels have traditionally been supplemented by visits to the mainland at least once a year, typically this has been at Christmas or prior to the start of the school term. The aim has been to purchase products unavailable on the islands that households anticipated they would need over the forthcoming six / twelve months. Freathy and Calderwood (2013) identified a number of issues with this activity. First, many residents considered it to be an expensive and time consuming exercise. Undertaking such a large numbers of purchases on a single trip would often impact upon cash flow. Families had to save for the occasion and there was always a concern about over spending. Secondly, the process could often lead to unnecessary purchases as it was not always possible to predict the exact number of items that were needed (see also Collins and Wellman 2010). E-commerce has the potential to reconfigure the purpose of mainland visits or even eliminate this activity altogether (Farag et al 2006a).

In summary, island retailing remains primarily concentrated in the urban centres, product choice and availability is often limited and prices remain higher than on the mainland. For those in more rural communities, travel to and from the towns is often time-consuming due to the noted difficulties in the transport infrastructure. Online availability has the potential to reduce the reliance upon shops in the main town and in the context of this paper, reconfigure mobility patterns. The extent to which e-commerce has reduced the number shopping trips to the main town or mainland remains uncertain. Patterns of behaviour amongst island residents 
remains complex and as previous research has identified, expressive factors, existing local grocery provision and a lack of confidence in some internet providers all appear to influence the travel patterns of island residents.

\section{Methodology}

For this study the Scottish island groups of Orkney, Shetland and the Outer Hebrides were chosen. The Scottish Government's Urban /Rural Eight Fold Classification 2011-2012 (Scottish Government 2012) identifies these locations as being 'Very Remote Rural ${ }^{21}$ with each having a single 'Very Remote Small Town' (a population of between 3,000 and 10,000). Having access to only one primary urban space limits consumer choice by restricting the opportunity to regularly use alternative retail centres. In the context of this research, such constraints help identify and isolate the impact that internet shopping can have upon a specific location.

Each of the three locations used in this study are comprised of a number of islands that vary in size, population, and level of commercial provision. For example, Lewis / Harris in the Outer Hebrides is approximately 79 miles in length, has a population of just under 20,000 and a mix of local and national retailers. In contrast, Papa Stour in the Shetland Isles has a population of 23 , just over 3 miles of tracked road and no store. The first objective of this research was to categorise each island based upon the range and type of retailers that respondents had access to. Three types were identified (Table 1).

Table 1: Island Types

\footnotetext{
${ }^{2}$ Very remote rural areas are defined as having a drive time of more than 60 minutes from a settlement of more than 10,000 people.
} 


\begin{tabular}{|l|l|l|}
\hline Type & Criteria & Examples \\
\hline One & $\begin{array}{l}\text { Has at least one established retail centre } \\
\text { with national retail multiples present }\end{array}$ & $\begin{array}{l}\text { Isle of Lewis and Harris, Orkney, } \\
\text { Shetland Mainland }\end{array}$ \\
\hline Two & $\begin{array}{l}\text { Islands with retail presence but no } \\
\text { national multiple retailer }\end{array}$ & Isle of Ghiga, Isle of Rhum \\
\hline Three & Islands with no formal retail provision & Isle of Muck, Papa Stour \\
\hline
\end{tabular}

The first category (Type One) comprises those islands large enough to sustain a national multiple presence and due to their size, accommodate a variety of organisational forms (convenience stores, supermarkets and superstore) and fascias. Typically these islands have both an urban and rural catchment area as well as a number of independent retail operators. Whilst having a population that can sustain a retail presence, a number of smaller islands around the Scottish coast have no national multiples and are serviced by one or more independent operator, a community group or a social enterprise (Type Two). These businesses often support smaller, more dispersed island communities and may occupy multiple roles (Byrom et al 2001; Calderwood and Freathy 2011). Finally, despite having a permanent population, a small number of Scottish islands have no established retail provision. These communities rely upon products being ordered and transported by boat from the larger islands or the mainland (Type Three). By providing this categorisation the research will determine whether patterns of consumer mobility are influenced by the level of retail provision available on each island.

The questionnaire confirmed that respondents had access to the internet and identified the form of connectivity (broadband / dial up). The island type (one, two or three) and the distance each respondent lived in relation the main town was also recorded. A number of early consumer studies established that patterns of shopping behaviour were influenced by the types of products being bought (Belk 1975; Howard and Sheth,1969; Tauber 1972). Because grocery shopping includes the purchase of staple, perishable food items, for many 
households it represents the most common and most frequent form of retailing activity.

While purchase patterns vary, research suggests that consumers may typically undertake a primary grocery shop supplemented by a number of smaller, 'top up' store visits (Piacentini et al., 2001; Thomas and Bromley 1993). This pattern of shopping behaviour may be contrasted with the less frequent acquisition of non perishable items such as garden furniture and sporting equipment. Given this variation and the central importance of grocery retail to consumption practices, the research examined whether the internet had specifically influenced the purchase behaviour or travel patterns of grocery shoppers. It identified where each respondent undertook their primary and secondary grocery shop and the frequency with which they visited these stores. To identify whether the internet had impacted upon overall travel patterns respondents were asked whether on-line access had influenced the number of trips they made into town and the mainland for either food or non food items.

Altogether 2077 questionnaires were distributed to resident households across three islands (Table 2). In order to identify any spatial patterns in e-shopping, questionnaires were distributed at varying distances to the main town (due to their size, Type Two and Three islands were omitted from this exercise). Where possible, questionnaires were distributed at the mid-point in each category (for example at the 15 minute point in the 10 minute - 20 minute category). However in some of the more remote island locations, communities were dispersed over a broader area and as a consequence the drive times had to be expanded in each category. In addition, no Type Two islands were surveyed on the Outer Hebrides. Although islands such as Scalpay and Bernera were previously separated from the main island, these are now connected by causeways that allow vehicle access and therefore do not 
fit the research criteria. Altogether 396 responses were received by the closing date of which 388 were usable. All data were coded and analysed using SPSS.

Table 2: Questionnaire distribution and returns by island type

\begin{tabular}{|c|c|c|c|c|c|c|}
\hline & $\begin{array}{l}\text { Total } \\
\text { Number } \\
\text { Distributed }\end{array}$ & $\begin{array}{l}\text { Numbers returned by } \\
\text { Island Group }\end{array}$ & $(\mathrm{N})$ & $\begin{array}{l}\text { Numbers retu } \\
\text { by drive time } \\
\text { main town (m }\end{array}$ & & (N) \\
\hline $\begin{array}{l}\text { Type } \\
\text { One }\end{array}$ & 1850 & $\begin{array}{l}\text { Orkney } \\
\text { Outer Hebrides } \\
\text { Shetland }\end{array}$ & $\begin{array}{c}92 \\
114 \\
139\end{array}$ & $\begin{array}{l}\text { Urban } \\
10-20 \text { mins } \\
21-30 \text { mins } \\
31-60 \text { mins } \\
60+\end{array}$ & $\begin{array}{l}- \\
-\end{array}$ & $\begin{array}{r}141 \\
74 \\
63 \\
35 \\
32\end{array}$ \\
\hline $\begin{array}{l}\text { Type } \\
\text { Two }\end{array}$ & 165 & $\begin{array}{l}\text { Orkney } \\
\text { Outer Hebrides } \\
\text { Shetland }\end{array}$ & $\begin{array}{c}12 \\
0 \\
19\end{array}$ & & & \\
\hline $\begin{array}{l}\text { Type } \\
\text { Three }\end{array}$ & 62 & $\begin{array}{l}\text { Orkney } \\
\text { Outer Hebrides } \\
\text { Shetland }\end{array}$ & $\begin{array}{l}8 \\
3 \\
1\end{array}$ & & & \\
\hline Total & & & 388 & & & \\
\hline
\end{tabular}

Due to the complexity of consumer shopping patterns and the relatively small sample sizes on Type Two and Three islands, qualitative interviews were held with 39 island residents (approximately $10 \%$ of respondents who had participated in the quantitative research phase) (Table 3). This stage of the research was designed to provide a deeper insight into the complexities of island shopping behaviour as well as answer specific issues identified in the quantitative research phase.

Table 3: Number of individuals interviewed by island type

\begin{tabular}{|l|l|l|l|}
\hline & Type One & Type Two & Type Three \\
\hline Shetland & 10 & 3 & 1 \\
\hline Orkney & 10 & 2 & 1 \\
\hline
\end{tabular}




\begin{tabular}{|l|l|l|l|}
\hline Outer Hebrides & 11 & & 1 \\
\hline
\end{tabular}

Altogether over 19 hours of qualitative research material was recorded. All interviews were conducted by telephone and data were subsequently transcribed and analysed with key themes being identified through the use of established content techniques (Hsieh and Shannon 2005). Each individual narrated their own personal shopping experiences and expanded upon issues identified in the quantitative research phase. The research aimed to construct a picture of how individuals shopped and to identify specific patterns of internet usage across a variety of locations and range of product categories.

This research has a number of limitations. First, no attempt is made to differentiate between the island groups. The three locations are viewed homogenously. As a consequence, any inter-island differences are not detailed or discussed. Secondly, this research defined travel pattern as the number of times each respondent travelled to the main town in order to shop. It did not require individuals to disaggregate this information by the mode of transport used, the routes taken or the total time travelled. It recognises that collecting such data could further enhance our understanding of consumer mobility on the islands. Thirdly, the research was conducted during the late Summer / early Autumn and does not consider whether mobility patterns vary during other times of the year. Finally, although the response rate from this research (19\%) falls within the 10\% - 40\% levels expected from a general population survey (Cao 2012), Draugalis and Plaza (2009) note that to minimise non response error, a return rate of between $50 \%-60 \%$ is optimal. As a consequence, this survey sample may not be representative of the target population and the conclusions drawn may not necessarily be 
applicable to other island groups. This limitation will be reflected in the future research questions that are derived at the end of this investigation.

\section{Findings}

The research identified that broadband provision on the islands was widespread and that internet usage amongst respondents was high with $95 \%(n=351)$ of respondents maintaining that they had on-line access and $92 \%(n=341)$ having a broadband connection. Only $6 \%$ of respondents stated that they had not accessed the internet over the past month while $85 \%$ maintained they had made at least one on-line transaction during that period.

\section{Mobility Patterns on Type One Islands}

The first stage of the research was to identify whether internet availability had influenced the total number of shopping trips that an individual made to the main island town (Lerwick, Stornoway or Kirkwall) over the past five years ${ }^{3}$. Approximately $66 \%(n=203)$ of respondents felt the number of visits had remained the same while a further $12 \%(n=38)$ maintained that the number had increased. Although it was acknowledged that the internet could both reduce travel time as well as a reliance upon public transport, almost $80 \%$ of respondents maintained that on-line availability had not reduced the number of shopping journeys made to the main town.

\footnotetext{
${ }^{3}$ It was recognised at the outset that respondents may have difficulty commenting upon their shopping behaviour over a five year period. For this reason the research only requested broad behavioural indicators (i.e. Increased / Decreased / Stayed the same) rather than asking respondents to detail the specific number of journeys made. The five year timescale was chosen as it represented the period over which traditional dial up services have been replaced by faster broadband connections on the islands. However the limitation that accompany this question are fully acknowledged.
} 
The results did however identify significant differences in mobility based upon an individual's drive time to the main town (Table 4). The majority of urban respondents $(73 \%)$ stated that internet access had not influenced the number of trips made to the main town. Similarly, the majority of those living between 10 and 30 minutes drive time from the urban centre also maintained that the number of trips were unaffected. In contrast, those respondents with a drive time in excess of 60 minutes were most likely to have reduced the number of visits made.

Table 4: Visits to main town

\begin{tabular}{|c|c|c|c|c|c|c|}
\hline $\begin{array}{l}\text { Visits to } \\
\text { main town }\end{array}$ & $\begin{array}{c}\text { Urban } \\
(\%)\end{array}$ & $\begin{array}{c}10-20 \text { mins } \\
(\%)\end{array}$ & $\begin{array}{c}21-30 \text { mins } \\
(\%)\end{array}$ & $\begin{array}{c}31-60 \text { mins } \\
(\%)\end{array}$ & $\begin{array}{c}60+\text { mins } \\
(\%)\end{array}$ & Total \\
\hline Increased & $10(7.9)$ & $17(23.6)$ & $5(8.2)$ & $4(12.9)$ & $2(12.5)$ & 38 \\
\hline Decreased & $24(18.9)$ & $12(16.7)$ & $10(16.4)$ & $12(38.7)$ & $8(50.0)$ & 66 \\
\hline $\begin{array}{l}\text { Stayed } \\
\text { Same }\end{array}$ & $93(73.2)$ & $43(59.7)$ & $46(75.4)$ & $15(48.4)$ & $6(37.5)$ & 203 \\
\hline Total & $\begin{array}{l}127 \\
(41.4)\end{array}$ & $72(23.5)$ & 61 (19.9) & $31(10.1)$ & $16(5.2)$ & 307 \\
\hline $\begin{array}{l}\chi^{2}=28.197 \\
\mathrm{df}=8 \\
\operatorname{sig}=.000\end{array}$ & & & & & & \\
\hline
\end{tabular}

Although Lee et al., (2009) noted the modest impact that internet adoption could have upon travel patterns, given the previously noted issues surrounding island retailing, it is perhaps surprising that e-commerce has not had a greater impact upon consumer mobility. Moreover, such findings do little to support previous research. For example, Ren and Kwan (2009) suggested that for people with limited retail access, the internet represented a more efficient channel that would significantly reduce or even eliminate the need to travel. To help interpret 
the findings from this study, the research therefore examined whether specific situational factors could help explain the modest impact upon respondents mobility.

An exploratory study of island retailing by Freathy and Calderwood (2013) examined whether the requirement to food shop was a significant determinant of shopping behaviour. They identified that the spatial distribution of island stores had a major influence upon travel patterns. Where rural island communities had access to a good quality grocery offer, trips into the main town were reduced and the number of on-line purchases increased. A symbiotic relationship was therefore identified between grocery provision, e-shopping behaviour and patterns of consumer mobility.

This study revealed that while national grocery multiples operate across all three island groups they are confined almost exclusively to the main town and, at the time of the research, did not offer an on-line service to island residents. One retailer provided a home delivery option (on the main isle) where customers could have shopping delivered to their home. Orders however could not be placed electronically and customers were required to first visit the store. In these circumstances internet availability did little to assist residents. While individuals are able to order certain grocery items from web-sites such as Amazon (e.g. toiletries, baby products) when purchasing perishable items they are required to either physically visit a store or rely upon alternative retail channels (such as a mobile shop).

The opportunity to shop for groceries outside the main urban centre therefore remains limited and consumer access to grocery provision on all three main islands is constrained by the location of the retail stores. For example, Figure 1 details grocery outlets on the island of Lewis / Harris. 
Figure 1: Retail Food Stores within 30 minute drive time of Stornoway

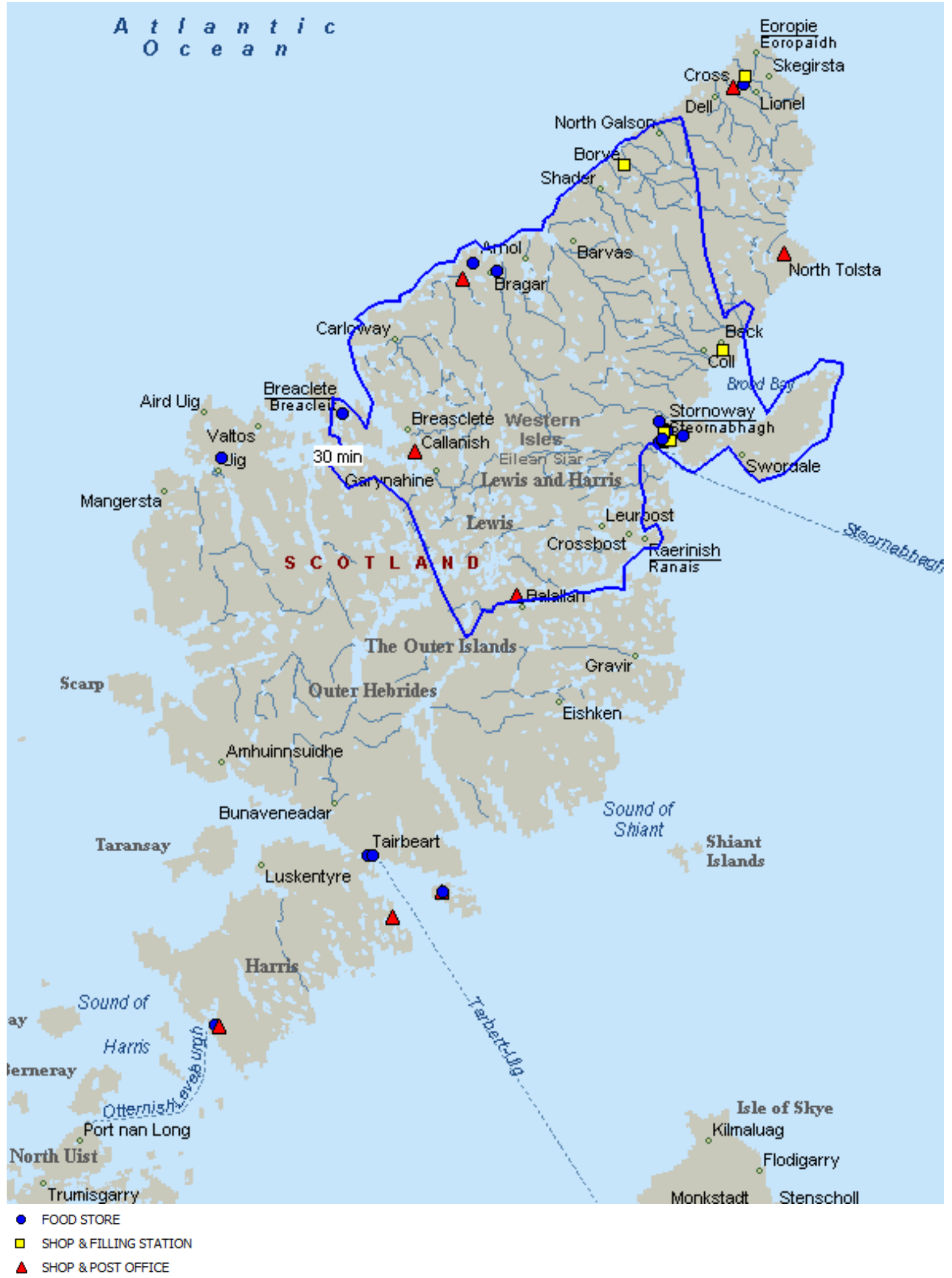

SHOP \& POST OFFICE 
While superstores and supermarkets remain concentrated in the main towns, outside of the urban area, grocery provision is primarily delivered through small, independent retailers, post offices and petrol stations. Such outlets may be specialists (eg butcher / baker) or limited line grocers with a narrow range of fresh, frozen and chilled goods. Moreover, as an OFT study (2012) concludes, these stores are typically more expensive than retailers in the towns. The majority of individuals living outside of the urban area have to either shop at these small stores or travel to the main urban centre. The research noted that on average respondents travelled 9.6 miles to undertake their primary grocery shop and, as Table 5 highlights, the overwhelming majority of residents on Type One islands travelled into the main town $(85 \%$, $\mathrm{n}=291$ ). Only $15 \%$ of respondents used the local store for their main shop, the majority of whom lived $60+$ minutes from the main town.

Table 5: Distance travelled to undertake main grocery shop

\begin{tabular}{|c|c|c|c|}
\hline & Local Store $(\%)$ & Main Town $(\%)$ & Total \\
\hline 1 mile or less & $28(56)$ & $95(32.6)$ & $123(36.1)$ \\
\hline $2-5$ miles & $15(30)$ & $17(5.8)$ & $32(9.4)$ \\
\hline $5-10$ miles & $6(12)$ & $53(18.2)$ & $59(17.3)$ \\
\hline $11+$ miles & $1(2)$ & $126(43.3)$ & $127(37.2)$ \\
\hline \multicolumn{1}{|r|}{ Total } & $50(15)$ & $291(85)$ & 341 \\
\hline $\begin{array}{l}\chi^{2}=53.48 \\
\text { df }=3 \\
\text { sig }=.000\end{array}$ & \multicolumn{3}{|}{} \\
\cline { 1 - 4 }
\end{tabular}

The next stage of the research was to consider whether the above observations could be used to group respondents into a series of broadly homogenous clusters. As noted previously, with consumer shopping behaviour becoming more complex, there have been increasing attempts to develop typologies based upon different patterns of internet usage. The objective for this 
study was to determine whether patterns of consumption displayed any spatial characteristics that would in turn allow identifiable taxonomies to be developed for island residents ${ }^{4}$.

A hierarchical cluster analysis was initially carried out using Ward's method and applying squared Euclidean Distance as the similarity measure. Ward's method was selected as it has the fewest inherent biases for calculating observations (Everitt et al 2001). This provided an agglomeration schedule that determined the optimum number of clusters. The procedure was then re-run and each case allocated to one of three clusters. Descriptive statistics calculated cluster centriods and mean values. To identify whether these were significantly different a one way ANOVA was used (Table 6).

Table 6: Hierarchical Cluster Analysis and F Values

\begin{tabular}{|l|l|l|l|}
\hline Cluster Label & $\mathbf{1}$ & $\mathbf{2}$ & $\mathbf{3}$ \\
\hline Mean Cluster Score & 2.56 & 1.68 & 2.93 \\
\hline Distance Travelled & 3.40 & 1.04 & 3.37 \\
\hline Where Shopped & 1.98 & 1.85 & 1.71 \\
\hline Location & 2.35 & 1.19 & 4.26 \\
\hline Number of Visits & 2.54 & 2.67 & 2.38 \\
\hline
\end{tabular}

\begin{tabular}{|l|l|l|l|}
\hline Dimension & $\boldsymbol{F}$ & Sig & \\
\hline Distance Travelled & 470.19 & .000 & \\
\hline Where Shopped & 16.14 & .000 & \\
\hline Location & 466.66 & .000 & \\
\hline Number of Visits & 3.52 & .031 & \\
& & & \\
\hline
\end{tabular}

As Table 6 indicates, the $\mathrm{F}$ values and mean differences are significant indicating that the variables reliably distinguish between each cluster. To determine where the differences lie, a

\footnotetext{
${ }^{4}$ The variables used included Distance Travelled (to undertake main grocery shop) Where Shopped (local store / main town centre store for primary shop), Residential Location (distance to main town) and Number of Visits (changes in the number of visits to the main town over the past five years).
} 
Tukey post hoc test revealed that the dimensions of Where Shopped and Location reliably differentiated the three clusters. The results therefore indicate:

Cluster 1: Comprises individuals who live between 10 and 30 minutes drive time from the urban centre, undertake their grocery shopping in the main town and whose travel patterns have been primarily unaffected by the development of the internet.

Cluster 2: These respondents both live and shop in the urban area. Because of their residential location, many are within a mile of a major retailer where they can undertake a main shop. Similar to cluster 1 , travel patterns have not been affected by the internet.

Cluster 3: This group live over 30 minutes drive time from the urban centre use a mixture of both local stores as well as the main town for grocery shopping. This group are most likely to have reduced the number of trips to the main town.

While cluster analysis relies upon personal judgement and offers only broad taxonomic groupings (Humphries et al., 2007), the findings do suggest that patterns of consumption amongst island residents display a spatial dimension. The influence of the internet upon travel patterns appears to be more significant the further an individual lives from the main town. To further understand the nature of these relationships a series of in-depth interviews were held with individuals in each cluster. The objective of the respondent interviews was to illustrate how specific situational factors can moderate or even negate the identified mobility benefits of internet adoption. The research did not seek to derive a list all factors that influenced consumer mobility patterns as the complexity and variety of different behaviours prevented this. 
Respondents were required to detail where and when they shopped in the main town and how the internet had influenced their travel patterns. While numerous reasons were put forward, the aim was to identify common factors that helped explain shopping behaviour. While the influence of grocery availability upon mobility patterns was reaffirmed during this phase, the motivations for continuing to shop in the main town were varied and did not arise simply from a deficiency in local grocery provision.

Those individuals who lived within the urban catchment area (Cluster 2) had easy access to the town. While the internet was regularly used for shopping and browsing, e-commerce was seen as an additional rather than substitute channel. Mobility patterns were therefore largely unaffected by the internet. Individuals continued to travel into the main town to shop for both food and non-food items. The national multiple grocery retailers were located within the urban area and this provided easy access to a range of providers. As one local resident noted:

"Like most town centres it is not as good as it used to be. But there again its better than quite a lot of places. We go in to shop at weekends. It gets me out of the house and I like to have lunch in the museum... Sometimes I just browse to see what is new.... I do use the internet as well... It is easy to use Tesco as a fridge, our two supermarkets are just on the outskirts of town which is fine as there's plenty of parking (Resident Cluster 2)".

The 'very remote rural' classification of each main town belies its central importance in the social and economic development of the islands. Schools, services and employment are concentrated in the urban centre and this was reflected in the research findings. Many individuals living outside of the urban area (Clusters 1 and 3) regularly commuted to work in 
the main town, brought their children to school or used public services. These journeys were then typically combined with grocery and non food shopping. As one resident noted:

"I no longer have to rely upon the ambulance as I have a motability car. When I visit the hospital in town I also do my food shopping at Tesco... I also try and do as much of my clothes shopping as possible when I am in the town ..." (Respondent Cluster 1)

For some individuals, shopping activities appear to be incorporated into their other domestic and work activities which in turn may partially explain the modest impact of the internet upon their travel mobility.

Freathy and Calderwood (2013) maintained that the limited distribution of grocery stores outside of the urban area prompted the need to shop in the main town. This research noted that this spatial limitation was accompanied by respondent concerns over product quality, range and availability. For example:

"The local post office, a mile away has got a little shop attached to it, basic groceries but the person who runs it, oh dear, oh dear, oh dear. It is unbelievably filthy. The last chap who had it, he was one of the locals and I must say he tried his best to keep it above ground and I think he succeeded because he sold it to some incomers and they've just lost it. I think these little shops, what keeps you going is the income from the post office. It has a few loaves of stale bread, the chap he's got a fishing boat and sticks a tray of mackerel down next to the grocery counter. He has a few tins of beans, a few tins of soup and things like that." (Resident Cluster 1)

Related concerns were similarly identified by other respondents. For example:

"We do our grocery shopping in the two supermarkets [in the main town] as we are not comfortable with what is available locally. [Before arriving on the island] We had access to fantastic non-supermarket food providers such as an organic veg box, and even more artisan producers. In Shetland you are more limited so if you want vegetables generally you have to go the Co-op or Tesco, so we very much do all of our shopping in either of those two stores. The whole food shop in Lerwick is really good and does sell some locally grown vegetables but it is a very limited choice and is not worth making a detour." (Resident Cluster 1) 
Conversely the research also noted how a good quality grocery offer in local stores could lead to a reduction in the number of trips made to the main town. In two separate locations, (each over one hour's drive time from the urban centre) the growth of on-line retailing had partially coincided with the opening of two community co-operatives. These outlets had opened with the support of the national Co-operative Group and offered a range of good quality, fresh and chilled products. The availability of this offer was seen as a situational factor that helped explain changes in respondent mobility. As one resident noted:

"The internet is really good but I still had to travel to Stornoway (the main town) at least once a week for my groceries. With the local shop now selling what they do, I hardly ever bother...." (Resident Cluster 3)

While having internet access was not in itself sufficient to generate a change in mobility patterns, when a quality grocery offer was also available, the need to travel was reduced.

\section{Mobility Patterns on Type Two and Three Islands}

The quantitative research received 43 responses from individuals living on Type Two and Three islands. Of these, 10 respondents maintained that internet availability had reduced the number of visits they made to the main town, while 22 said their trips were unaffected. Despite the issues associated with travel, the majority of respondents preferred to use the main town for their primary grocery shop (63\%).

The in-depth interviews sought to identify the factors that helped explain these mobility patterns. As with Type One respondents it was noted that visits to the town centre were frequently combined with other activities such as medical appointments, visits to the bank, the hairdresser or to the council. Moreover, while the Type Two islands were serviced by 
independents retailers, limitations were again noted in the available provision. Product range was seen as being either restricted or too expensive. As one respondent from a Type Two island noted:

"there is a good selection of stuff in them [the local store] but they are dearer. The likes of Tesco has everything under one roof, you can go there and get most things you need...Shopping for groceries in Tesco is much cheaper than shopping on the island but it costs you a bit to get there because of the ferry and the fuel so you generally tie it in with other things, maybe the bank. You'll maybe spend a day in Lerwick doing a few things. The ferry costs $£ 10$ for a car and then $£ 5$ per person and then your fuel."

Those individuals who had reduced the number of visits to the man town were able to identify the internet as having a direct impact upon their mobility patterns. As one individual commented:

"Previously the family would spend the whole day shopping and visiting the library but that has stopped now due to eBooks. The reasons for going to town has reduced, it tends to tie with a medical appointment or some other appointment .. that would be the designated shopping day for that month."

In this context the internet had helped reduce the number of shopping trips undertaken, individuals used a range of on-line services such as banking, travel and insurance and even library services.

\section{Mainland Trips}

The final stage of the research considered whether trips to the mainland had been influenced by the availability of the internet. As noted previously, many island residents traditionally visited the mainland at least once a year in order to purchase products unavailable in the local market. On-line provision has the potential to reduce or even eliminate these trips. Evidence 
from this research however suggests that the influence of e-shopping upon the propensity to travel to the mainland was again limited. The research identified that $69 \%$ of respondents visited the mainland at least once every six months while over $83 \%$ maintained that the number of visits made over the past 5 years had either increased or remained the same. This is perhaps unexpected given that previous research had highlighted the negative aspects of mainland visits.

Farag et al., (2006a) note that e-commerce has the potential to modify consumer travel behaviour and alter the principal purpose of the trip. Freathy and Calderwood (2013) identified that mainland trips were traditionally shopping orientated and primarily focused upon the purchase of school items and clothing. Individuals were constrained in both the number and variety of activities that they could undertake due to the limited time they had available. Table 7 details how respondents felt internet availability had modified their shopping behaviour.

Table 7: Influence of internet upon mainland shopping behaviour.

\begin{tabular}{|l|c|c|c|}
\hline Because of the internet ......... & Agree (\%) & $\begin{array}{c}\text { Neither Agree or } \\
\text { Disagree }\end{array}$ & Disagree \\
\hline $\begin{array}{l}\ldots . . \text { I spend less time shopping when on } \\
\text { mainland visits. }\end{array}$ & $113(33.1)$ & $98(28.7)$ & $130(38.1)$ \\
\hline $\begin{array}{l}\ldots . . \text { I now shop for different products } \\
\text { when on mainland visits. }\end{array}$ & $119(35)$ & $116(34.1)$ & $105(30.8)$ \\
\hline $\begin{array}{l}\ldots . . \text { I spend less money shopping when } \\
\text { on mainland visits. }\end{array}$ & $108(31.8)$ & $88(25.9)$ & $144(42.4)$ \\
\hline $\begin{array}{l}\ldots . . \text { trips to the mainland are now more } \\
\text { leisurely. }\end{array}$ & $139(40.8)$ & $114(33.4)$ & $88(25.8)$ \\
\hline $\begin{array}{l}\ldots . . \text { I now undertake other activities on } \\
\text { mainland visits (e.g. visiting friends, } \\
\text { restaurants, theatre etc). }\end{array}$ & $172(49.7)$ & $106(30.6)$ & $68(19.6)$ \\
\hline
\end{tabular}


While consumer travel patterns remain largely unaffected the results indicate that the largest proportion of respondents spend less time shopping and although many individuals felt they were unlikely to spend less money on such trips, they now shop for different products undertake other activities (such as short breaks and visits to the theatre) and find the overall experience more leisurely.

\section{Conclusions}

Hjorthol and Gripsrud's (2009) observation that the impact of e-shopping upon mobility patterns remained unclear, may in part be explained by the situational factors that influence an individual's propensity to travel (Hand et al., 2009). Understanding behaviours therefore requires an understanding of the specific geographical contexts within which the research takes place. The first aim of this paper was to examine whether internet availability has had an impact upon the number of shopping trips made by island residents. While there was some evidence that internet adoption had reconfigured travel patterns, it can be concluded that the overall impact upon mobility has been modest. Although the findings noted both substitution and generation effects, on-line availability appears to have had a neutral outcome for the majority of island residents (Mokhtarian and Salomon, 2002). This was consistent across all island types and reinforced the findings of previous research (Rotem-Mindali, and Salomon, 2007).

Given the limited impact of the internet upon the travel patterns of island residents, the second aim of the paper was to understand the situational factors that influenced the shopping decision (Hand et al., 2009). The concentration of employment and public services within the urban area meant that many island residents were regularly required to travel into the 
main town. As the majority of island retailers were located in the urban area, individuals combined these trips with a range of different shopping activities. Perhaps more significantly, an understanding of mobility patterns cannot be separated from an understanding of the islands existing grocery provision. Freathy and Calderwood (2013) identified the limited number of grocery stores outside the urban area and this research noted the absence of an on-line service for perishable products. In addition, respondents also expressed dissatisfaction with the quality, range, availability and price of local providers. As a consequence individuals were prepared to continue to travel to the main town in order to undertake their primary shop (Farag et al 2006a; Mokhtarian and Salomon, 2002).

The symbiotic relationship between shopping mobility and access to grocery provision highlights the complex nature of consumer travel patterns. Moreover it illustrates how situational factors can limit the benefits provided by on-line availability and help explain why previous research has appeared inconclusive (Cairns, 2005; Rotem-Mindali and Salomon, 2007). This is not to suggest that the impact of the internet has been inconsequential in the lives of island residents and these findings perhaps mask a more fundamental reconfiguration of shopping behaviours. As the mainland visits confirmed, the activities undertaken while on such trips have altered significantly and, as the responses from the qualitative research suggest, the number of stores visited, the range of products bought and the amount of money spent on the island may have changed appreciably.

Finally, this investigation has highlighted a number of issues that may further inform future policy development. The Scottish Government has explicitly articulated its support for the creation of a world class digital infrastructure by 2020 (Scottish Government, 2013) and while the consumer benefits of e-commerce have been identified, this research suggests that 
the policy impacts that stem from such initiatives may display distinct spatial variations. While on-line availability has the potential to reduce shopping related travel, this is mediated or even negated by the islands social and economic environments. Broadband availability is unlikely to compensate for deficiencies in the transport infrastructure nor overcome the negative externalities of the transport system given the existing limitations of the retail grocery sector (Rotem-Mindali and Salomon 2007).

Paradoxically, rather than strengthening the competiveness of the island's retail sector, the growth of e-commerce may also serve to reinforce existing patterns of regional disadvantage. Goods and services traditionally purchased locally are now bought 'off island' and therefore constitute a form of 'outshopping' (Lee et al, 2009). Given the fragility of many island economies, this 'trade leakage' is likely to disproportionately affect local businesses. However, the extent of this impact and the reaction of the retail sector to the challenges posed by e-commerce remains uncertain and merits further research.

In conclusion, the internet represents an empowering mechanism that has the potential to fundamentally reconfigure both travel patterns and shopping behaviour. However the consumer related benefits commonly associated with e-commerce may be mediated by a wide variety of specific, situational factors. The implications of this extend beyond identifiable differences in academic research studies towards an explanation of spatial variations in the impact of Government policy initiatives. 


\section{References}

Armstrong, H., Johnes, G. and McBean, A. (1991) Consumer Goods and Energy Prices on the Isle of Man, Management Research News; 14 (7) 31-35

Barnes, S., Bauer, H., Neumann, M. and Huber, F. (2007) Segmenting cyberspace: a customer typology for the internet, European Journal of Marketing 41 (1/2) 71-93

Belk, R. (1974) Situational Variables and Consumer Behavior, Journal of Consumer Research, 2(3), pp. 157-164.

Boase, J. (2010) The Consequences of Personal Networks for Internet Use in Rural Areas, American Behavioral Scientist 53 (9) pp.1257 - 1267)

Boschma, R. and, Weltevreden, J. (2008), "An evolutionary perspective on Internet adoption by retailers in the Netherlands", Environment and Planning A 40 (9) 2222 - 2237.

Byrom, J., Medway, D. and Warnaby, G. (2003) Strategic alternatives for small retail businesses in rural areas, Management Research News; 26 (7) 33-49

Byrom, J., Medway, D. and Warnaby, G. (2001) Issues of provision and "remoteness" in rural food retailing: A case study of the Southern Western Isles of Scotland, British Food Journal, 103 (6) 400-413

Cairns, S. (2005), “'Delivering supermarket shopping: more or less traffic? " Transport Reviews 25 (1) 51 - 84.

Calderwood, E. and Freathy, P. (2011) Challenges in the supply of perishable products to island communities, The International Review of Retail, Distribution and Consumer Research, 21(2) 145 - 160

Cao, X. (2012) The relationships between e-shopping and store shopping in the shopping process of search goods, Transportation Research Part A: Policy and Practice, 46(7), pp. 993-1002.

Collins, J. and Wellman, B. (2010) Small Town in the Internet Society: Chapleau Is No Longer an Island, American Behavioral Scientist 53 (9) pp.1344 - 1366

Copus, A. and Crabtree, B. (1992) Mapping Economic Fragility: an Assessment of the Objective 5b Boundaries in Scotland, Journal of Rural Studies, 8 (3) pp. 309-322.

Couclelis, H. (2000). From sustainable transportation to sustainable accessibility: can we avoid a new tragedy of the commons? In Janelle, D. and Hodge, D., (eds.) Information, Place, and Cyberspace: issues in accessibility. Berlin: Springer-verlag pp. 342-356.

Dholakia, U., Kahn, B., Reeves, R., Rindfleisch, A., Stewart, D. and Taylor, E., (2010) Consumer Behavior in a Multichannel, Multimedia Retailing Environment, Journal of Interactive Marketing, 24 (2) pp. 86 - 95 
Donthu, N. and Garcia, A. (1999), "The Internet shopper", Journal of Advertising Research, 39 (3) $52-8$

Draugalis, J. and Plaza, C. (2009) Best Practices for Survey Research Reports Revisited: Implications of Target Population, Probability Sampling, and Response Rate, American Journal of Pharmaceutical Education, 73(8) p.142.

Everitt, B., Landau, S. and Leese, M. (2001), Cluster Analysis, 4th ed., Arnold, London.

Farag, S., Schwanen, T., Dijst, M and Faber, J. (2007) "Shopping online and/or in-store? A structural equation model of the relationships between e-shopping and in-store shopping" Transportation Research Part A: Policy and Practice, 41 (2) pp. 125-141.

Farag, S., Krizek, K. J., and Dijst, M. (2006a). E-shopping and its relationship with in-store shopping: empirical evidence from the Netherlands and the U.S. Transport Reviews, 26, 4361.

Farag, S., Weltevreden, J., van Rietbergen, T., Dijst, M., and van Oort, F. (2006b), "Eshopping in the Netherlands: does geography matter?" Environment and Planning B: Planning and Design 33(1) 59 - 74

Freathy, P. and Calderwood, E. (2013) The impact of Internet adoption upon the shopping behaviour of island residents, Journal of Retailing and Consumer Services 20 (1) pp. 111119.

Galloway, L. (2007),"Can broadband access rescue the rural economy?", Journal of Small Business and Enterprise Development, 14 (4) pp. 641 - 653

Ganesh, J., Reynolds, K., Luckett, M. and Pomirleanu, N.(2010) Online Shopper Motivations, and e-Store Attributes: An Examination of Online Patronage Behavior and Shopper Typologies Journal of Retailing 86 (1) 106-115

Habib, K., Day, N. and Miller, E. (2009) An investigation of commuting trip timing and mode choice in the Greater Toronto Area: Application of a joint discrete-continuous model, Transportation Research Part A: Policy and Practice, 43(7), pp. 639-653.

Hale, T., Cotten, S. Drentea, P. and Goldner, M. (2010) Rural-Urban Differences in General and Health-Related Internet Use American Behavioral Scientist 53 (9) pp.1304 - 1325

Hand, C., Dall'Olmo Riley, F. Harris, P. Singh, J. and Rettie, R. (2009),"Online grocery shopping: the influence of situational factors", European Journal of Marketing, 43 (9) pp. $1205-1219$

Hjorthol, R. (2009) "Information searching and buying on the Internet: travel-related activities?" Environment and Planning B: Planning and Design 36(2) 229 - 244

Hjorthol, R. (2002) The relation between daily travel and use of the home computer, Transportation Research Part A: Policy and Practice, 36(5), pp. 437-452. 
Hjorthol, R. and Gripsrud, M. (2009) Home as a communication hub: the domestic use of ICT, Journal of Transport Geography, 17 (2) 115-123

Howard, J. and Sheth, J. (1969) The theory of buyer behavior, New York, Wiley

Hsieh, H-F. and Shannon, S. (2005) Three Approaches to Qualitative Content Analysis, Qualitative Health Research, 15 (9) 1277-1288.

Humphries, A., Towriss, J. and Wilding, R. (2007),"A taxonomy of highly interdependent, supply chain relationships: The use of cluster analysis", The International Journal of Logistics Management, 18 (3) pp. 385 - 401.

Kau, A., Tang, Y. and Ghose, S. (2003) 'Typology of online shoppers' Journal of Consumer Marketing, 20 (2) 139-156

Kellerman A, (2010), "Mobile broadband services and the availability of instant access to cyberspace" Environment and Planning A 42 (12) 2990 - 3005.

Kilkenny, M. (2010) Urban/Regional Economics and Rural Development, Journal of Regional Science, 50 (1) pp. 449-470.

Krizek, K. J., Li, Y., and Handy, S. L. (2005). Spatial attributes and patterns of use in household-related information and communications technology activity. Transportation Research Record, 1926, 252-259.

Larson, M. (2009) Issues Monitor, Sharing Knowledge on the Retail Industry, KPMG International, January, Volume Two, http://www.kpmg.com/Ca/en/IssuesAndInsights/ArticlesPublications/Documents/Issuesmonit orRetailVol2Jan09.pdf (last accessed 4th October 2011)

Lee, D., Paswan, A., Ganesh, G. and. Xavier' M. (2009) Outshopping Through the Internet: A Multicountry Investigation, Journal of Global Marketing 22(1) 53 - 66.

Lyons, G. and Urry, J. (2005). Travel time use in the information age.

Transportation Research Part A: Policy and Practice, 39 (2-3), 257-276.

McEachern, M. and Warnaby, G. (2006) Food shopping behaviour in Scotland: the influence of relative rurality, International Journal of Consumer Studies,30 (2) pp. 189-201.

Mewett, P. G., (1983) Economic brokerage and peripheral underdevelopment in the Isle of Lewis, Sociological. Review, 31, 427-52

Mokhtarian, P. (1990) A Typology of Relationships Between Telecommunications and Transportation. Transportation Research Part A 24 (3), 231 - 242

Mokhtarian, P. and Salomon, I (2002) Emerging Travel Patterns: Do Telecommunications make a difference?, in H. Hahmassani (ed) In Perpetual Motion: Travel Behavior Research Opportunities and Application Challenges, Bingley, Emerald Publishing.

Morrison, P. and Clark A (2011), "Internal migration and employment: macro flows and micro motives" Environment and Planning A 43 (8) 1948 - 1964. 
OFT (2012) "Price and choice in remote communities: Call for Evidence" OFT Report 1420, Office of Fair Trading, , http://www.oft.gov.uk/shared_oft/consultations/remotecommunities/OFT1420.pdf. Last accessed 23rd August 2013.

Piacentini, M., Hibbert, S. Al-Dajani, H. (2001) Diversity in deprivation: exploring the grocery shopping behaviour of disadvantaged consumers, The International Review of Retail, Distribution and Consumer Research 11, (2), pp.141-158.

Prattis, J. (1982)_Unemployment and Job Creation: A Case Study from the Western Isles of Scotland, Management Research News, 4 (3) 16-20

Ren, F, and Kwan M-P, 2009, "The impact of geographic context on e-shopping behavior" Environment and Planning B: Planning and Design 36(2) $262-278$

Richards, C. (2004) Information technology and rural development, Progress in Development Studies 4,3 pp. 230-244.

Roberts, D. (2005) The role of households in sustaining rural economies: a structural path analysis, European Review of Agricultural Economics, 32 (3) pp. 393-420.

Rohm, A., and Swaminathan, V. (2004). A typology of online shoppers based on shopping motivations. Journal of Business Research, 57(7) 748 - 757

Rotem-Mindali, O. and Salomon, I. (2009) Modelling consumers' purchase and delivery choices $\mathrm{n}$ the face of the information age, Environment and Planning B: Planning and Design 36 (2) pp.245-261

Rotem-Mindali, O. and Salomon, I. (2007) The impacts of E-retail on the choice of shopping trips and delivery: Some preliminary findings, Transportation Research Part A: Policy and Practice, 41(2), pp. 176-189.

SAC (2012) Rural Scotland in Focus, Rural Policy Centre, Scottish Agricultural College.

Salomon, I. (1986) “Telecommunications and travel relations: a review”, Transportation Research Part A, vol. 20(3), pp. 223-238,

Salomon, I. and Koppelman, F. (1988) A Framework for Studying Teleshopping versus Store Shopping, Transportation Research Part A: Policy and Practice, 22A(4), pp. 247-255.

Scottish Government (2013) Scotland's Digital Future - Supporting the Transition to a World-leading Digital Economy, Edinburgh, Scottish Government.

Scottish Government (2012) Scottish Government Urban Rural Classification 2011-2012, available at:

http://www.scotland.gov.uk/Topics/Statistics/About/Methodology/UrbanRuralClassification/ Urban-Rural-Classification-2011-12 last accessed 11th February 2013.

Scottish Government (2010) Socio-Economic Briefing on Rural Scotland: Identifying Fragile Rural Areas Paper 5 Supporting Evidence Provided to the Rural Development Council 
Working Group, Crown Copyright, available at: http://www.scotland.gov.uk/Resource/Doc/320175/0102396.pdf last accessed 1st November 2012.

Scottish Government (2008) Highlands \& Islands Scotland: European Regional Development Fund 2007-2013 structural funds operational programme, Edinburgh, Scottish Government.

Shetland Islands Council (2004) Shetland Islands Shopping Survey 2003, Shetlands Islands Council

Sim L. and Koi S. (2002) Singapore's Internet shoppers and their impact on traditional shopping patterns, Journal of Retailing and Consumer Services, 9(2). 115-124

Skerratt, S. (1999) Food availability and choice in rural Scotland: the impact of "place", British Food Journal, 101 (7) 537-544

Stranahan, H. and Kosiel, D. (2007) "E-tail spending patterns and the importance of online store familiarity", Internet Research, 17 (4) 421 - 434

Stanley, J., Hensher, D., Stanley, J. and Vella-Brodrick D. (2011) Mobility, social exclusion and well-being: Exploring the Links Transportation Research Part A: Policy and Practice, 45(8), pp. 789-801.

Tauber, E. (1972) Why Do People Shop?, Journal of Marketing 36(4), pp.46 - 49.

Thomas, C. and Bromley, R. (1993), The impact of out-of-centre retailing, in Bromley, R. and Thomas, C. (Eds), Retail Change, Contemporary Issues, UCL Press Ltd, London.

Verhoef, P. and Langerak, F. (2001) Possible determinants of Consumers' adoption of electronic grocery shopping in the Netherlands, Journal of Retailing and Consumer Services, $8(5) 275-285$.

Weltevreden, J. (2006) Substitution or complementarity? How the Internet changes city centre shopping, Journal of Retailing and Consumer Services 14 (192 - 207).

Weltevreden, J., Atzema, O., Frenken, K., de Kruijf, K. and van Oort, F. (2008). The geography of Internet adoption by independent retailers in the Netherlands. Environment \& Planning B, 35 (3), 443-460

Wen, I. (2009),"Factors affecting the online travel buying decision: a review", International Journal of Contemporary Hospitality Management, 21 (6) pp. 752 - 765

Wigan, M. and Morris, J. (1981) The Transport Implications of Activity and Time Budget Constraints, Transportation Research Part A: Policy and Practice, 15 (a), pp. 63-86.

Wilkinson D. (2010), Community Cohesion and Canadian Rural E-Mail Behavior, American Behavioral Scientist 53 (9) pp. 1268 - 1282. 